\title{
Bir Üniversite Hastanesinde COVID-19 Pandemisinin İlk Yılında Laboratuvarda Dog̃rulanmıș Pozitif Olguların Özellikleri
}

\section{Characteristics of Laboratory-Confirmed Positive Cases in the First Year of the COVID-19 Pandemic in a University Hospital}

Candan ÇiçEK'(ID), Mehmet SOYLU'(IID), Muhammed Alper ÖZARSLAN'(iD), Merve MERT²(ID), Mükerrem Bahar BAȘKIR (ID), Șaziye Rüçhan SERTÖZ'(IID), Ayșin ZEYTiNOG̃LU'(IID),

Funda KARBEK AKARCA ${ }^{4}\left(\right.$ IID), Murat ERSEL ${ }^{4}(\mathrm{IID})$, Eylem ULAS SAZ $\mathrm{Z}^{5}$ (iiD), Meltem TAȘBAKAN²(IID),

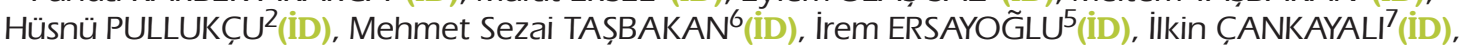

Tansu Gülbahar AYDOG̃AN'(IID), Furkan POLAT'(IiD), Ayça AYDIN UYSAL'(IID), Betül AKKUL'(IID), Gözde AKKUȘ'(ID), İrem Nur ȘAHIN'(ID), Ayșe NOYAN'(ID)

\footnotetext{
${ }^{1}$ Ege Üniversitesi Tıp Fakültesi Hastanesi, Tıbbi Mikrobiyoloji Anabilim Dalı, İzmir, Türkiye

${ }^{2}$ Ege Üniversitesi Tıp Fakültesi Hastanesi, İnfeksiyon Hastalıkları ve Klinik Mikrobiyoloji Anabilim Dalı, İzmir, Türkiye

${ }^{3}$ Bartın Üniversitesi Fen Fakültesi, Uygulamalı Matematik Anabilim Dalı, Matematik Bölümü, Bartın, Türkiye

${ }^{4}$ Ege Üniversitesi Tıp Fakültesi Hastanesi, Acil Tıp Anabilim Dalı, İzmir, Türkiye

${ }^{5}$ Ege Üniversitesi Tıp Fakültesi Hastanesi, Çocuk Sag̃lıg̃ı ve Hastalıkları Anabilim Dalı, İzmir, Türkiye

${ }^{6}$ Ege Üniversitesi Tıp Fakültesi Hastanesi, Göğüs Hastalıkları Anabilim Dalı, İzmir, Türkiye

${ }^{7}$ Ege Üniversitesi Tıp Fakültesi Hastanesi, Anestezi ve Reanimasyon Anabilim Dalı, Yog̃un Bakım Bilim Dalı, İzmir, Türkiye
}

Makale atıf: Çiçek C, Soylu M, Özarslan MA, Mert M, Başkır MB, Sertöz ŞR ve ark. Bir üniversite hastanesinde COVID-19 pandemisinin ilk yllında laboratuvarda doğrulanmış pozitif olguların özellikleri. FLORA 2021;26(3):446-59.

\section{ÖZ}

Giriş: Çin'in Wuhan kentinde Aralık 2019'da ortaya çıkan ve kısa zamanda tüm dünyayı etkisi altına alan yeni koronavirüs SARS-CoV-2 olarak adlandırılmış, neden olduğu olağandışı viral pnömoni kliniğine Dünya Sağlık Örgütü tarafından COVID-19 ismi verilmiş ve 11 Mart 2020 tarihinde pandemi ilan edilmiştir. Yeni etken dünyaya hızla yayılmış, tüm ülkeler gibi Türkiye de salgından olumsuz yönde etkilenmiştir. Bu çalısmada, Ege Üniversitesi Tıp Fakültesi (EÜTF) Hastanesine salgın başlangııından itibaren bir yıl içinde COVID-19 bulguları ile başvuran ve SARS-CoV-2 RT-PCR testi ile tanısı doğrulanan hastaların epidemiyolojik ve klinik özelliklerinin araştırılması amaçlanmıştır.

Materyal ve Metod: Mart 2020-Şubat 2021 tarihleri arasında SARS-CoV-2 RT-PCR testi pozitif olan pediatrik ve erişkin hastaların bir yıllık verileri retrospektif olarak incelendi. Hastaların başvurdukları servislere ve aylara göre yaş ve cinsiyet özellikleri tarandı ve infeksiyonu geçirme ağırlıkları hafif, orta ve ağır olmak üzere üç grupta irdelendi. Ağır kategorisindeki hastaların, toplumda sık gözlenen komorbid hastalıkları ile săg kalım durumları arasındaki ilişki değerlendirildi. İstatistiksel analizler, SPSS V.26.0 kullanılarak yapıldı.

Bulgular: Pandemi başlangıandan itibaren bir yıllık süre içinde EÜTF Hastanesine 75851 kişi COVID-19 şüphesi ile başvurdu. Başvuran hastaların yaş medyanı 39 (yaş aralığı 0-96) ve \%50.7'si erkek hastaydı. Bu hastaların 7951'i (\%10.5, yaş medyanı 39) ve toplamda COVID-19 şüphesi ile başvuran hem kadın hem de erkek hastaların \%10.5'i ( $p=0.796)$ pozitif bulundu. Hastaların 9274'ü (\%12.2) pediatrik, 66577'si (\%87.8) erişkindi. COVID-19 şüphesi ile başvuran pediatrik hastaların \%7.7'si ( $n=716)$, erişkin hastaların \%10.9'u $(n=7235)$ pozitif bulundu $(p=0.000)$. Hafif, orta, ağır olarak klinik sınılama yapılan hastaların oranları sırasılla \%92.7, \%3.4, \%3.9 bulundu. Her üç düzey olgu grubu için ikili karşılaştırmalar sonucunda hafif olgularla diğerleri arasında istatistiksel olarak anlamlı fark olduğu görüldü $(p=0.000)$. Ancak, orta ve ağır olgular arasında istatistiksel olarak anlamlı bir fark bulunmadı $(p=0.298)$. Hafif-orta-ağır 
klinik düzey dağıımları sırasıyla; erkeklerde 3.721 (\%50.4), 142 (\%52.7), 181 (\%58.7), kadınlarda 3.653 (\%49.5), 127 (\%47.2), 127 (\%41.2) oranlarında bulundu ( $p=0.014)$. Ağır klinik düzeydeki 308 hastanın 234 'ü (\%76.0) yoğun bakım hastasıydı. Sağ kalan ve ölen hastaların sigara içme, obezite, hipertansiyon (HT), diabetes mellitüs (DM), koroner arter hastalığı (KAH), konjestif kalp yetmezliği (KKY), kronik böbrek yetmezliği (KBY) ve kronik obstrüktif akciğer hastalı̆̆ (KOAH), malignite varlığı, kemoterapi öyküsü $p$ değerleri sırasıyla; $0.037,0.001,0.052,0.025,0.003,0.004,0.006,0.558,0.355,0.056$ bulundu. Toplam pozitif olan hastaların \%1.8'i (141/7951), ağır hastalık kategorisinde olan hastaların \%45.8'i (139 erişkin, 2 çocuk), yoğun bakımda tedavi edilen hastaların \%57.3'ü $(p=0.000),>60$ yaş üstü hastaların (70 erkek, 52 kadın) \%85'i ex oldu ( $p=0.000)$. Ex olan hastaların \%59.6'sı $(n=84)$ erkek, \%40.4'ü $(n=57)$ kadın hastaydı ( $p=0.791)$. COVID-19'un bir yıllık dağılımında, Kasım ayına ait pozitif olgular (\%36.8) en yüksek düzeyde bulundu.

Sonuç: Bir yıllık sürede COVID-19 hem pediatrik hem de erişkin grupta büyük oranda hastaneye yatış gerekmeksizin, hafif hastalık tablosu ile geçirilmiştir. COVID-19 bölgemizde \%10.5 oranında pozitif bulunmuştur. Toplumda kadın ve erkek eşit oranlarda COVID-19 ile infekte olmuş, ancak ağır klinik düzey hastalık tablosu erkeklerde ve 60 yaş üzerinde daha sık görülmüştür. COVID-19 olan hastaların \%1,8'i kaybedilmiştir. Ölüm oranları özellikle yoğun bakımda tedavi gören hastalarda yüksek oranlarda bulunmuştur. Sigara içme öyküsü, obezite, DM, KAH, KKY, KBY komorbiditeleri ile >60 yaş; kötü prognoz ve ölüm ile ilişkili bulunmuştur. Büyük olasılıkla Ekim sonundaki İzmir depremine bağlı olarak COVID-19, Kasım 2020'de pik yapmıştır.

Anahtar Kelimeler: Pandemik; SARS-CoV-2; Polimeraz zincir reaksiyonu; Eşzamanlı hastalık

\section{ABSTRACT \\ Characteristics of Laboratory-Confirmed Positive Cases in the First Year of the COVID-19 Pandemic in a University Hospital}

Candan ÇiÇEK', Mehmet SOYLU', Muhammed Alper ÖZARSLAN', Merve MERT², Mükerrem Bahar BAȘKIR ${ }^{3}$, Șaziye Rüçhan SERTÖZ', Ayșin ZEYTiNOG̃LU', Funda KARBEK AKARCA ${ }^{4}$, Murat ERSEL ${ }^{4}$, Eylem ULAȘ SAZ ${ }^{5}$,

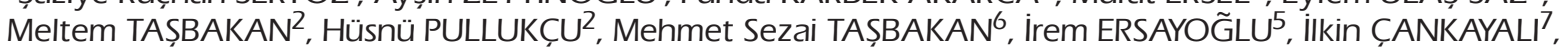
Tansu Gülbahar AYDOG̃AN', Furkan POLAT'1, Ayça AYDIN UYSAL'1, Betül AKKUL', Gözde AKKUȘ!', İrem Nur ȘAHIN', Ayșe NOYAN'

\footnotetext{
${ }^{1}$ Department of Medical Microbiology, Ege University Faculty of Medicine Hospital, İzmir, Turkey

${ }^{2}$ Department of Infectious Diseases and Clinical Microbiology, Ege University Faculty of Medicine Hospital, İzmir, Turkey

${ }^{3}$ Department of Applied Mathematics, Division of Mathematics, Bartın University Faculty of Science, Bartın, Turkey

${ }^{4}$ Department of Emergency Medicine, Ege University Faculty of Medicine Hospital, İzmir, Turkey

${ }^{5}$ Department of Pediatrics, Ege University Faculty of Medicine Hospital, İzmir, Turkey

${ }^{6}$ Department of Chest Diseases, Ege University Faculty of Medicine Hospital, İzmir, Turkey

${ }^{7}$ Department of Anesthesiology and Reanimation, Division of Intensive Care, Ege University Faculty of Medicine Hospital, İzmir, Turkey
}

Introduction: The new coronavirus named SARS-CoV-2, emerged in Wuhan, China in December 2019 and caused a pandemic. Unusual clinic of viral pneumonia caused by this virus was named COVID-19 and pandemic was declared on 11 March 2020 by World Health Organization. In this study, it was aimed to investigate the epidemiological and clinical characteristics of pediatric and adult patients who were admitted to Ege University Faculty of Medicine (EUFM) Hospital, Izmir, Turkey with COVID-19 findings between March 2020 and February 2021 and whose diagnosis was confirmed by the SARS-CoV-2 RT-PCR test.

Materials and Methods: Age and gender characteristics of the patients were screened according to the services and months they admitted to the hospital, and the severity of infection was evaluated in three groups as mild, moderate and severe. In the severe patient group, the relationship between the common comorbid diseases observed in the community and survival status of patients were also evaluated. All statistical analysis performed by SPSS V.26,0.

Results: One year from the start of the pandemic, 75851 people applied to the EUFM Hospital with the suspicion of COVID-19. The age median of the patients who applied was 39 (age-range; 0 -96) and $50.7 \%$ were male patients. SARS-CoV- 2 were detected in a total of 7951 (10.5\%, median age 39) patients, of them 4044 (10.5\%) were male and 3907 (10.5\%) were female $(p=0.796)$. All of the patients, 66577 (87.8\%) were adults and 9274 (12.2\%) were children. The rate of positivity for SARS-CoV2 in pediatric and adult groups were $7.7 \%(n=716)$ and $10.9 \%(7235)$, respectively $(p=0.000)$. The percentage of patients who were classified as mild, moderate, and severe were $92.7 \%, 3.4 \%$, and $3.9 \%$, respectively. As a result of paired comparisons for all three level case groups, a statistically significant difference was found between mild cases and others $(p=0.000)$. However, there was no statistically significant difference between moderate and severe cases $(p=0.298)$. The mild-moderate-severe clinical level distributions were $3721(50.4 \%)$, 
142 (52.7\%), 181 (58.7\%) in male, 3653 (49.5\%), 127 (47.2\%), 127 (41.2\%) in female, respectively ( $p=0.014)$. All severe clinical level patients, 234 (76\%) were intensive care patients. Smoking, obesity, hypertension (HT), diabetes mellitus (DM), coronary artery disease (CAD), congestive heart failure (CHF), chronic renal failure (CRF), chronic obstructive pulmonary disease (COPD), malignancy, and chemotherapy $p$ values were found $0.037,0.001,0.052,0.025,0.003,0.004,0.006,0.558,0.355,0.056$, respectively.

Conclusion: As a result, in a one-year period, COVID-19 showed up a mild illness in both the pediatric and adult groups without the need for hospitalization. In the community, women and men were equally infected with COVID-19, but severe-clinical-level disease was more common in men and over 60 years of age. Mortality rates were found to be high, especially in patients treated in intensive care. Smoking, obesity, DM, CAD, CHF, CRF comorbidities and being $\geq 60$ years old, associated with poor prognosis and death. Due to the Izmir earthquake at the end of October, COVID-19 peaked in Izmir, in November 2020.

Key Words: Pandemics; SARS-CoV-2; Polymerase chain reaction; Comorbidity

\section{GiRiș}

Koronavirüsler 21. yüzyılda bir dizi salgınla yeni halk sağlığı sorunu haline gelmişlerdir. Zoonotik kökenli yüksek derecede patojenik iki koronavirüs, 2002'de "Severe Acute Respiratory Syndrome Coronavirus" (SARS-CoV) ve 2012'de "Middle-East Respiratory Syndrome Coronavirus" (MERS-CoV) salgınlarıyla ortaya cıkmıs ve insanlarda ölümcül solunum yolu hastalığına neden olmuștur ${ }^{[1]}$. Aralık 2019'da üçüncü kez ağır alt solunum yolu infeksiyonuna neden olan yeni bir tip koronavirüs, bu kez Cin'in Wuhan kentinde ortaya cıkmıs ve kısa zamanda tüm dünyayı etkileyen büyük bir salgına dönüșmüștür. $\mathrm{Bu}$ yeni virüs; SARS-CoV-2 olarak adlandırılmıs ve olağandıșı viral pnömoni salgınına neden olmuștur. COVID-19 (Coronavirus Disease) olarak da bilinen bu yeni infeksiyon, oldukça bulașıcı olduğundan tüm dünyaya hızla yayılmıs hem infekte olmus insan sayısı hem de salgın alanları açısından SARS ve MERS'in olușturduğu etkiyi ezici bir sekilde geçmiștir. Dünya Sağlık Örgütü (DSÖ) tarafından 11 Mart 2020 tarihinde pandemi ilan edilmistirir ${ }^{[2]}$.

Salgının bașlangıcında COVID-19 infeksiyonu geçiren olguların özellikleri Cin'den yapılan yayınlarda duyurulmus, daha sonra tüm ülkelerden genis seriler seklinde rapor edilmeye bașlanmıștır. COVID-19 hastalığının klinik belirtileri asemptomatik hastalıktan akut solunum sıkıntısı sendromuna (ARDS) neden olan ciddi interstisyel pnömoni ve ölüme kadar uzanan geniș bir yelpazede görülmektedir $^{[3,4]}$. Cin'de yapilan ilk serilerde hastanede yatan hastaların yas ortalamasının orta ve ileri yașlarda olduğu (medyan yaș 56), erkek cinsiyetin ön planda (\%62) olduğu ve özellikle hipertansiyon (HT) ve diabetus mellitus (DM) gibi komorbiditesi olan hastaların infeksiyonu daha ağır geçirdiği ve mortalite riskinin arttığı bildirilmiștir ${ }^{[5]}$. Ocak 2020 sonu itibariyle virüsün Avrupa'ya yayılması sonucunda İtalya'da yapılan ilk calıșmalarda daha ağır klinik tablolar ve daha yüksek mortalite riski (\%23) ortaya cıkmıstır. İnfekte olan hastaların coğunluğunun hospitalize edildiği (\%80), erkek (\%72) ve yas medyanın 65 olduğu ve hastaların yarısından fazlasinda (\%56) en sik HT, koroner arter hastalığı (KAH) ve DM'nin ön planda bulunduğu bildirilmiștir $^{[6]}$. 2020 ortalarına doğru, Avrupa ve Amerika Birlesik Devletleri'nde (ABD) mortalite riskinin hesaplandığı bir calıșmada, İtalya, İspanya, Yunanistan ve ABD'deki hastalar incelenmiș; hastaların yas medyanının 68, \%60'ının erkek olduğu; DM ve KAH'ı olan 80 yas üstündeki hastalarda infeksiyonun daha yüksek oranlarda ölümle sonuçlandığı bildirilmiștir ${ }^{[7]}$.

Türkiye'de ilk olgu birçok Avrupa ülkesindeki ilk bildirimlerden daha sonra, 11 Mart 2020 tarihinde ilan edilmiștir. Nisan 2020'de olgu sayıları bașta İstanbul olmak üzere cok yüksek sayılara ulașmıștır. Nisan 2021 sonlarına gelindiğinde, salgin son hizıyla dünyada ve ülkemizde devam etmektedir. İki yüz on sekiz ülkede 145 milyondan fazla doğrulanmıs vaka ve infeksiyon nedeniyle 3 milyondan fazla ölüm bulunmaktadır. Aynı tarih itibariyle ülkemizde 4,5 milyon doğrulanmıș olgu ve 37 bin ölüm gerçekleșmiștir ${ }^{[2,8]}$. COVID-19 salgını, küresel halk sağlığı için olağanüstü bir tehdit olușturmaya devam etmektedir.

Bu calısmada, Ege Üniversitesi Tıp Fakültesi Hastanesi'ne salgın bașlangıcından itibaren bir y1l içinde COVID-19 bulguları ile bașvuran ve SARS-CoV-2 RT-PCR testi ile tanısı doğrulanan hastaların epidemiyolojik ve klinik özelliklerinin araștırılması amaçlanmıștır. 


\section{MATERYAL ve METOD}

Ege Üniversitesi T1bbi Mikrobiyoloji Laboratuvarına, T.C. Sağlık Bakanlığı tarafından 23 Mart 2020 tarihinde SARS-CoV-2 RT-PCR testinin uygulanma yetkisi verildi. $\mathrm{Bu}$ tarihten sonra $\mathrm{CO}-$ VID-19 infeksiyonu süphesi ile Ege Üniversitesi Tip Fakültesi Hastanesi'ne bașuran tüm hastalar kayıt altına alındı. Subat 2021 sonu itibariyle SARS-CoV-2 RT-PCR testi pozitif olan pediatrik (0-18 yaș) ve yetișkin (19 yas ve üzeri) hastalara ait bir yillk veriler retrospektif olarak hastane elektronik kayit sisteminden elde edildi. Hastalarin bașvurdukları servislere ve aylara göre yaș ve cinsiyet özellikleri tarandı ve infeksiyonu gecirme ağırlıkları üc farklı kategoride incelendi.

Pediatrik hastaların "hafif" (klinik belirti yok veya akciğer görüntüleme sonuçları normal, ancak SARS-CoV-2 RT-PCR testi pozitif veya hafif üst solunum yolu semptomları var), "orta" (pnömoni, ates ve öksürük, radyolojik bulguları olan ve serviste tedavi gören hastalar) ve "ağır" (belirgin hipoksemi ve solunum desteğine ihtiyaç duyan ve yoğun bakımda tedavi gören hastalar) tanımları yapıldı ${ }^{[9]}$. Erișkin hastalar, T.C. Sağlık Bakanlığı tarafindan 7 Mayıs 2021 tarihinde yayınlanan "COVID-19 (SARS-CoV-2 İnfeksiyonu) Erișkin Hasta Tedavisi" "10] kılavuzu önerileri doğrultusunda "hafif" (ateș, kas, eklem ağrıları, öksürük ve boğaz ağrısı gibi bulguları olup solunum sıkıntısı olmayan -dakika solunum sayısı <24, $\mathrm{SpO}_{2}>$ \%93 oda havasında- ve akciğer filmi ve/veya akciğer tomografisi normal olan hastalar), "orta" (ates, kas, eklem ağrıları, öksürük ve boğaz ağrısı gibi bulguları olup, solunum sayısı <30/dakika olan, oda havasinda $\mathrm{SpO}_{2}>90$ üzerinde olan ve akciğer grafisinde veya tomografisinde hafif-orta pnömoni bulgusu olan hastalar) ve "ağır" (ates, kas, eklem ağrıları, öksürük ve boğaz ağrısı gibi bulguları olup, takipnesi ( $\geq 30 /$ dakika) mevcut, oda havasında $\mathrm{SpO}_{2}$ düzeyi $\leq \% 90$ altında olan ve akciğer grafisinde veya tomografisinde bilateral yaygın pnömoni bulgusu saptanan hastalar) olarak üc farklı klinikte gruplandırıldı. "Ağır" kategorisindeki hastaların, sık gözlenen komorbiditeleri [HT, DM, KAH, konjestif kalp yetmezliği (KKY), kronik böbrek yetmezliği (KBY), KOAH], malignite varlığı (hematolojik veya solid organ), kemoterapi [KT] öyküsü, obezite ve sigara içme öyküsü var- lığı), diğer esslik eden komorbiditeler (operasyon gecirme, Alzheimer, romatoid artrit vb romatolojik hastalıklar, demans, hipotiroidi, parkinson, serebrovasküler bozukluklar vb) ve exitus durumları ayrıca kaydedildi.

Tüm COVID-19 süpheli hastalardan nazofarenks sürüntü örnekleri bașvurdukları poliklinik veya servislerde güvenli kabinlerde alındıktan sonra viral nükleik asid tamponu (VNat, Bioeksen, Türkiye) içinde en kısa zamanda viroloji laboratuvarına gönderildi. Kayıtların tarandığı bir yıllık sürede hastalardan alınan sürüntü örneklerinin gönderildiği VNat solüsyonu hem tașıyıc1 besiyeri hem de viral RNA'nin serbestlestirilmesinde kullanıldı. Ege Üniversitesi Tıbbi Mikrobiyoloji Laboratuvarında, T.C. Sağlık Bakanlığı'nın tüm yetkili laboratuvarlarda kullanımını onayladığı üc farklı firmanın SARS-CoV-2 RT-PCR testleri (Bio-Speedy ${ }^{\circledR}$ SARS-CoV-2, Bioeksen/Diagnovital SARS-CoV-2 RT-PCR, RTA/Coronex RT-qPCR, Gensutek, Türkiye) etkenin saptanmasında üretici firmanın önerileri doğrultusunda kullanıld ${ }^{[11-13]}$. Tüm amplifikasyon ișlemleri ve analizler Rotorgene (Qiagene, Lüksemburg) cihazı ile yapıldı.

İstatistiksel analizler, Windows için SPSS istatistik yazılımı, V.26.0 (SPSS, Chicago, Illinois, ABD) kullanılarak yapıldı. Veriler Excel 2016 ve S/R programlamada kod yazımı ile görselleștirildi. Verilerin normalliğini test etmek için Shapiro-Wilk testi kullanıldı. Bağımsız iki örneklem arasındaki fark, normal dağılımlı kitlelerden alınmıș örneklemler için bağımsız iki örneklem t testi; normal dağılım varsayımını sağlamayan örneklemler için Mann-Whitney U-testi kullanılarak incelendi. İkiden fazla bağımsız örneklem karșılaștırmaları, normal dağılım varsayımın sağlanmadığı durum için Kruskal Wallis H testi ile yapıldı. Coklu karșlaștırmalar için genel ortalama rank değeri ile gruplara ait ortalama rank değerleri kıyaslandı, ayrıca ikili karșlaștırmalar için Mann Whitney U testi kullanıldı. Kategorik iki değișken arasında istatistiksel olarak anlamlı bir ilișki (fark) olup olmadığı ki-kare bağımsızlık testi ile incelendi. Sonuçlar, sayılar (n), frekanslar (\%), medyanlar ve değișim aralığı (min-maks) olarak sunuldu. İstatistiksel testler için 0,05'ten kücüik bir p değeri anlaml kabul edildi.

Sağlık Bakanlığı'ndan resmi izin ve Ege Üniversitesi, Tıbbi Araștırmalar Etik Kurulu'ndan ça- 
lıșma protokolü onayı alındı (21-5.1T/54, 2705 2021).

\section{BULGULAR}

23 Mart 2020 ile 28 Subat 2021 tarihleri arasında Ege Üniversitesi Tip Fakültesi Hastanesi'ne 75851 kiși COVID-19 süphesi ile bașvurdu. Başvuran hastaların yas medyanı 39 , yas ortalaması 41.2 21.3 (yas aralığ1 0-96) ve \%50.7'si $(n=38.475)$ erkek hastaydı. Bu hastaların 7951'i (\%10.5) pozitif bulundu (yas medyanı 39 (0-96), yas ortalaması $40.78 \pm 18.8)$. COVID-19 șüphesi ile bassuran erkek hastaların \%10,51'i $(n=4044)$, kadın hastaların \%10.45’i $(n=3907)(p=0.796)$ pozitif bulundu.

$\mathrm{Bu}$ tarihler arasında bașvuran hastaların 9274 'ü (\%12.2) pediatrik, 66.577'si (\%87.8) eriskin hastayd. COVID-19 süphesi ile bassvuran pediatrik hastaların \%7.7'si $(n=716)$, eriskin hastaların \%10.9'u ( $\mathrm{n}=7235)$ pozitif bulundu $(\mathrm{p}=0.000)$.

Bassvuran hasta cinsiyetlerine göre SARS-CoV-2 RT-PCR testi sonuçlarının aylara göre pozitif ve negatif oranlar1 Sekil 1'de, pozitif bulunan pediatrik ve eriskin hastaların yașlara göre dağılımları Tablo 1'de gösterildi.
Hafif, orta, ağır olarak klinik sınıflama yapılan hastaların oranları sırasiyla \%92.7, \%3.4, \%3.9 bulundu. Bir yil boyunca aylik olarak gözlenen hafif, orta, ağır düzeydeki toplam pozitif olgu sayıları Sekil 2'de, pediatrik-erișkin ayırımları Tablo 2 'de gösterildi.

Her üc düzey olgular için genel ve ikili karșlaștırmalar sonucunda hafif olgularla diğerleri arasında istatistiksel olarak anlamlı fark olduğu görüldü $(p=0.000)$. Orta ve ağır olgular arasında istatistiksel olarak anlamlı bir fark bulunmadı $(p=$ 0.298).

Cinsiyete göre klinik düzey dağılımları Sekil 3'te gösterildi. Hafif-orta-ağır klinik düzey dağılımları sırasılya; erkeklerde 3721 (\%50.5), 142 (\%52.8), 181 (\%58.8), kadınlarda 3653 (\%49.5), 127 (\%47.2), 127 (\%41.2) oranlarında bulundu $(\mathrm{p}=0.014)$.

Pozitif bulunan hastalar içinde, ağır klinik düzeydeki 308 hastanın 234'ü (\%76.0) yoğun bakım hastasıydı. Bunlardan, 300 eriskin hastanın 226'sı (\%75.3), sekiz pediatrik hastanın tümü yoğun bakımda tedavi edildi. Ağır kategorisinde bulunan sekiz pediatrik hastanın beșinin komorbid hastalıkları (Fallot tetralojisi, sağ kalp yetmezliği-ex, ma-

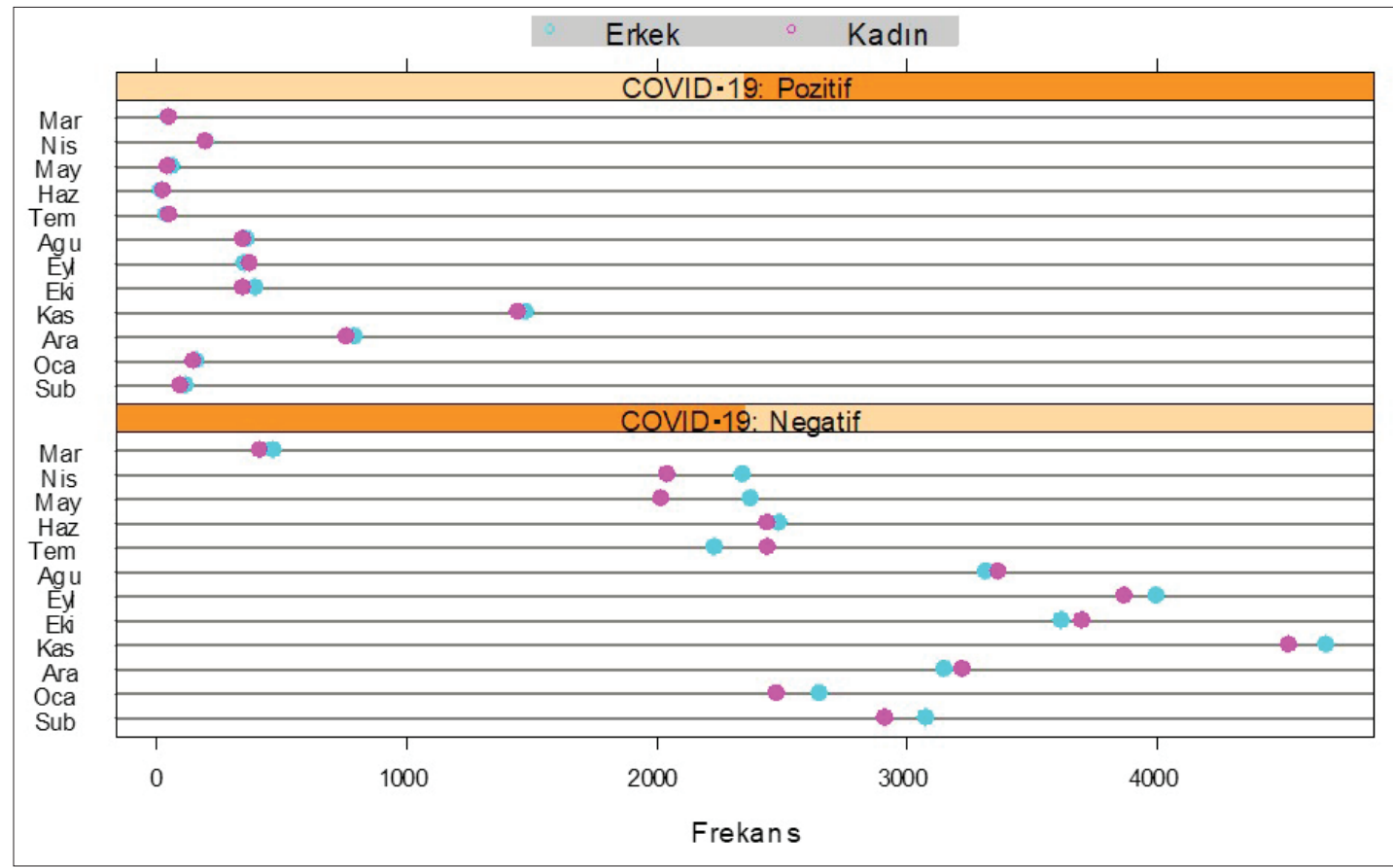

Şekil 1. SARS-CoV-2 RT-PCR test sonuçlarının dağılımı. 
Tablo 1. Pozitif bulunan pediatrik ve erişkin hastaların yaş dağılımları

\begin{tabular}{|c|c|c|}
\hline & Yaş aralığı & $\mathrm{n}(\%)$ \\
\hline \multirow{9}{*}{ Pediatrik (0-18 yaş) } & $0-1$ & $82(11.4)$ \\
\hline & $2-3$ & $55(7.7)$ \\
\hline & $4-5$ & $47(6.6)$ \\
\hline & $6-7$ & $51(7.1)$ \\
\hline & $8-9$ & $48(6.7)$ \\
\hline & $10-11$ & $54(7.5)$ \\
\hline & $12-13$ & $77(10.8)$ \\
\hline & $14-15$ & $111(15.5)$ \\
\hline & $16-18$ & $191(26.7)$ \\
\hline \multicolumn{3}{|c|}{ Toplam: 716 (\%7.7) } \\
\hline \multirow{14}{*}{ Erişkin (19-96 yaş) } & $19-24$ & $812(11.2)$ \\
\hline & $25-30$ & $1135(15.7)$ \\
\hline & $31-36$ & $982(13.6)$ \\
\hline & $37-42$ & $959(13.3)$ \\
\hline & $43-48$ & $806(11.1)$ \\
\hline & $49-54$ & $635(8.8)$ \\
\hline & $55-60$ & $594(8.2)$ \\
\hline & $61-66$ & $457(6.3)$ \\
\hline & $67-72$ & $328(4.5)$ \\
\hline & $73-78$ & $248(3.4)$ \\
\hline & $79-84$ & $181(2.5)$ \\
\hline & $85-90$ & $80(1.1)$ \\
\hline & $91-96$ & $18(0.3)$ \\
\hline & \multicolumn{2}{|c|}{ Toplam: 7235 (\%10.9) } \\
\hline
\end{tabular}

lign obez, olası primer immün yetmezlik-ex, KC nakli) bulunuyordu. Toplam komorbidite oranları ve olguların özellikleri Tablo 3'te gösterildi. Toplam pozitif olan hastaların \%1.8'i (141/7951), ağır hastalık kategorisinde olan hastaların \% 45.8 'i (141/308), yoğun bakımda tedavi edilen hastaların \%57.3'ü $(134 / 234)$ ex oldu $(p=0.000)$. Ex olan hastaların \%59.6'sı $(n=84)$ erkek, \%40.4'ü $(\mathrm{n}=57)$ kadın hastaydı $(\mathrm{p}=0.791)$. Ağır kliniği olan 300 erișkin hastanın 139'u (\%46.3), 8 çcuk hastanın 2'si (5 aylik kiz ve 7 aylik erkek bebek) ex oldu. Ex olan hastaların $<60$ yas (\%15) ve $\geq 60$ yas ve üstü $(\% 85)$ oranları karșlaștırıldığında, coğunluğunun 60 yas ve üzeri hasta olduğu görüldü $(p=0.000)$. 60 yaș ve üstü ex olan 120 kișinin $\% 57.5$ 'i $(n=69)$ erkek, \%42.5'i $(n=$ 57) kadindı (p 0.23).
Bir yıl boyunca yapilan toplam test içinde pozitif olguların (yedi hareketli ortalama bașına toplam test-pozitif olgu ile) dağılımı Şekil 4'te gösterildi. Kasım ayına ait pozitif olgular, bir yıllık pozitif olguların \%36.8 ( $\mathrm{n}=2927)$ 'i idi. 16 Kasım 2020 tarihinde en yüksek pozitif olgu sayısı $(n=$ 187, \%2.35) gözlendi. Toplam test sayılarındaki artıs ile saptanan pozitif olguların sayısı da aynı düzeyde artış gösterdi. Günlük hafif seviyedeki olgu sayları pozitif olgu sayları ile benzer seyirde ilerledi. Orta ve ağır seviyedeki olgular benzer seviyede eğilim gösterdi. Hafif seviyedeki olguların 16 Kasım 2020'de ( $\mathrm{n}=177)$, orta seviyedeki vakaların 28 Mart 2020'de ( $\mathrm{n}=9$ ), ağır seviyedeki vakaların ise 9 ve 14 Aralı 2020'de ( $n=7)$ en yüksek değerde olduğu görüldü. Bir yıl içerisindeki COVID-19 pozitif olguların 


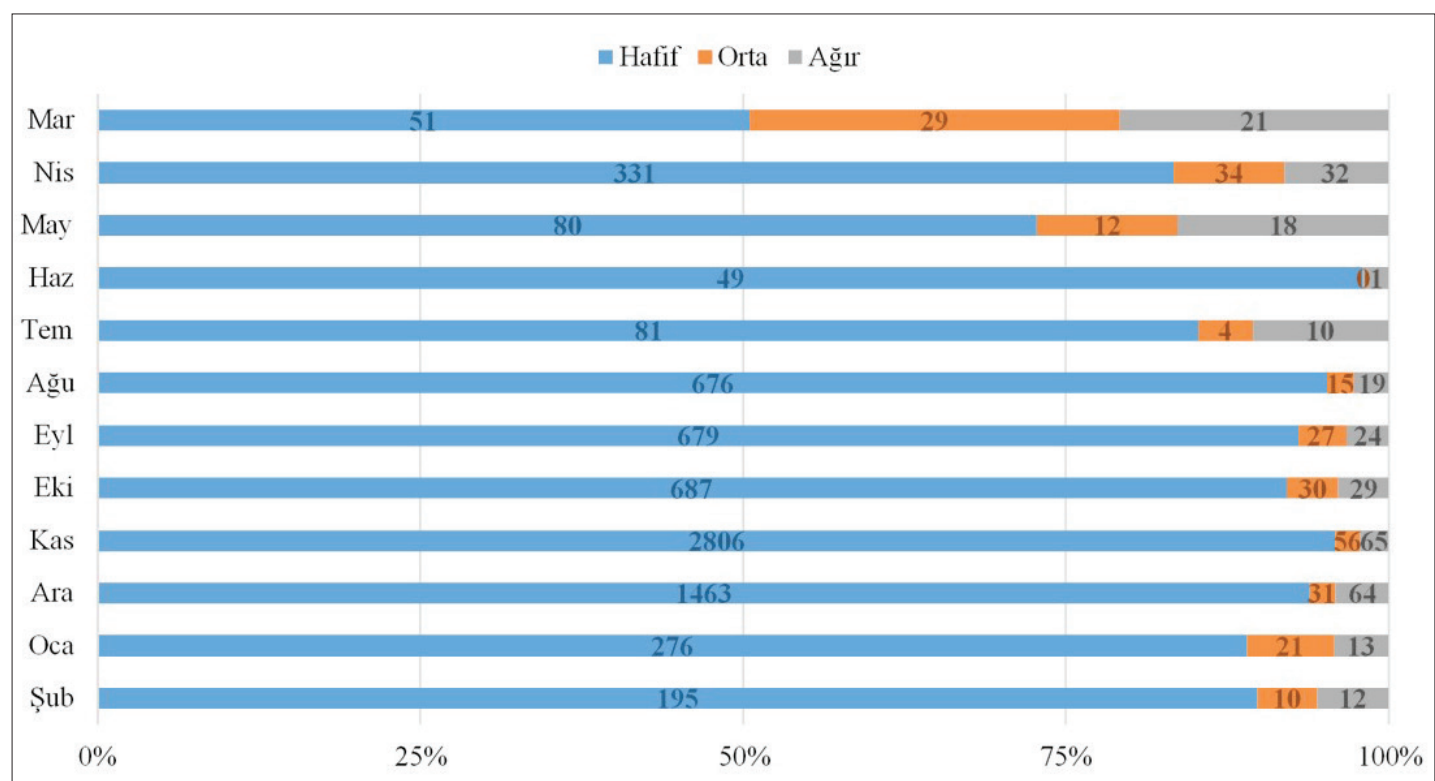

Şekil 2. Klinik düzeylerin aylara göre dağılımı.

Tablo 2. SARS-CoV-2 RT-PCR pozitif olan hastaların özellikleri

\begin{tabular}{|c|c|c|c|c|}
\hline Hastaların özellikleri & $\begin{array}{c}\text { Pediatrik }(n=716) \\
n(\%)^{*}\end{array}$ & $\begin{array}{c}\text { Erişkin }(n=7235) \\
n(\%)^{*}\end{array}$ & p & $\begin{array}{c}\text { Total }(\mathrm{n}=7951) \\
\mathrm{n}(\%)^{*}\end{array}$ \\
\hline Medyan (yaş aralığı) & $12(0-18)$ & $41(19-96)$ & & $39(0-96)$ \\
\hline $\begin{array}{l}\text { Cinsiyet } \\
\text { Kadın } \\
\text { Erkek }\end{array}$ & $\begin{array}{l}328(45.8) \\
388(54.2)\end{array}$ & $\begin{array}{l}3579(49.5) \\
3656(50.5)\end{array}$ & 0.062 & $\begin{array}{l}3907(49.1) \\
4044(50.9)\end{array}$ \\
\hline $\begin{array}{l}\text { Klinik düzey } \\
\text { Hafif } \\
\text { Orta } \\
\text { Ağır }\end{array}$ & $\begin{array}{c}708(98.9) \\
0 \\
8(1.1)\end{array}$ & $\begin{array}{c}6666(92.1) \\
269(3.7) \\
300(4.2)\end{array}$ & 0.000 & $\begin{array}{c}7374(92.7) \\
269(3.4) \\
308(3.9)\end{array}$ \\
\hline
\end{tabular}

aylara göre dağılımı pediatrik grup (0-18 yaș) için Sekil 5'te, erișkin hasta grubu için Sekil 6'da paylassıld. Pediatrik hastaların $0-1$ yas aralığında \%11.2'si (79/708) hafif, \%0,0'1 (0/0) orta, $\% 37.5$ 'i (3/8) ağır, 12-18 yas aralığında \%53’ü (375/708) hafif, \%0.0'1 (0/0) orta, \%50.0'si (4/8) ağır; erișkin hastaların 19-48 yas aralığında \%68.2'si (4545/6666) hafif, \%37.5'i (101/269) orta, \%16'sı (48/300) ağır klinik düzey oranları bulundu $(\mathrm{p}=0,000)$.

\section{TARTIȘMA}

Bu çalıșmada, ülkemizde ilk bildirim yapıldıktan sonraki bir yil içinde, tek merkezde hastaneye COVID-19 semptomları ile bașvuran kișilerde, SARS-CoV-2 RT-PCR testi ile pozitif bulunan hastaların özellikleri ve salgının bölgemizdeki yıllık dağılımı geriye yönelik olarak incelenmiștir. Özellikle pozitif bulunan hastaların yas, cinsiyet, $\mathrm{CO}-$ VID-19 klinik düzeyi ve infeksiyonu ağır geciren hastaların risk faktörleri irdelenmistir. COVID-19 infeksiyonu sıklığı bir yıllık süre içinde bölgemizde toplam hasta sayısı üzerinden \%10.5 oranında pozitif bulunmuștur. Erișkin hasta grubunda COVID-19 pozitifliği istatistiksel olarak önemli oranda pediatrik gruptan daha fazla görülmüstür. T.C. Sağlık Bakanlığı haftalık verilerine göre, Mayis 2021 itibariyle, İzmir'de her 100.000 kișide 223,34 kișinin infekte olduğu bildirilmiștir. Bu makale yazıldığı tarihlerde, Mayıs 2021 ortası verilerine göre Türkiye dünyada toplam 5.139.485 


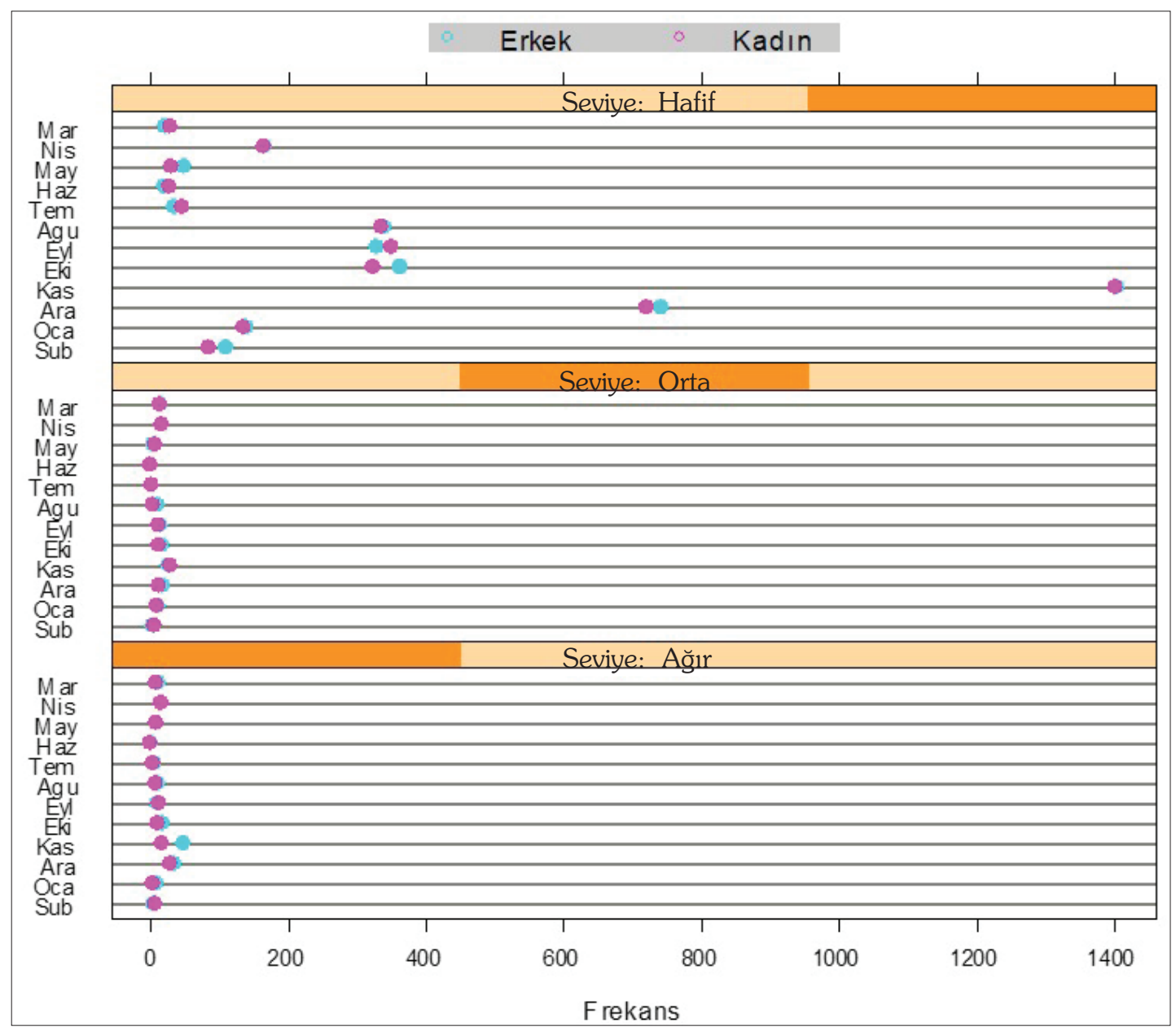

Şekil 3. Cinsiyete göre klinik düzeylerin dağııımı.

olgu sayısı ile COVID-19'un en sık görüldüğüu beșinci ülke konumundadır ${ }^{[14]}$.

COVID-19 infeksiyonu olan pediatrik hastaların yas medyanı 12 ve erkek hasta oranı \%54.3, erișkin hastaların yas medyanı ise 41 ve erkek hasta oranı \%50.6'dir. Pediatrik ve eriskin pozitif hastaların yas dağılımlarına bakıldığında, pediatrik grubun 0-1 yas ve 12-18 yas aralığında, erişkin grubun ise 19-48 yas aralığında kümelendiği görülmektedir. Pandeminin bașında infeksiyon-laktasyon ilișkisinin cok iyi bilinmemesi ve maternal izolasyonun 0-1 yas grubunda uygulanmaması nedeniyle bu grupta infeksiyon oranları yüksek seyretmiștir. Okul öncesi çă̆ın daha iyi korunduğu, okulların açılma-kapanma yasakları arasında en fazla 16-18 yas grubunun salgından olumsuz yönde etkilendiği görülmüștür. Bu yas grubu sınavlar nedeniyle okula ve yüz yüze eğitime katıldıkları için diğer evde eğitim gören yas gruplarına oranla virüse daha fazla maruz kalmıslardır. Eriskin grupta ise, is ve sosyal hayatı aktif olan yas grubunda infeksiyon daha yaygin seyretmiștir. COVID-19 olan kadın-erkek oranları arasında istatistiksel olarak anlamlı bir fark bulunmamıstır. Daha önce yapılan sistematik derlemelerde pediatrik hastaların yas medyanı 7-9.5, erișkin hastaların yas medyanı ise 47 ve her üc grupta hastaların \%58'inin erkek olduğu bildirilmiștir ${ }^{[15-17]}$. Bu calıșmadaki seride pediatrik hastaların yas medyanları daha yüksek, eriskin hastaların yas medyanı daha düșüktür ve erkek-kadın cinsiyet oranları birbirine yakındır. $\mathrm{Bu}$ durum bulunduğumuz bölgenin yas ortalaması, ülke olarak SARS-CoV-2'ye karș1 alınan korunma önlem ve yasakları, ayrıca kișilerin bunlara uyma 
Tablo 3. "Ağır hasta" kategorisindeki SARS-CoV-2 pozitif hastaların özellikleri

\begin{tabular}{|c|c|c|c|}
\hline Hastaların özellikleri & $\begin{array}{c}\text { Sağ kalanlar }(n=167) \\
n(\%)^{*}\end{array}$ & $\begin{array}{c}\text { Ex olanlar }(n=141) \\
n(\%)^{*}\end{array}$ & $\begin{array}{l}\text { Toplam } \\
\text { n (p) }\end{array}$ \\
\hline Yaş medyan (aralık) & $61(1-87)$ & $73(0-96)$ & $66(0-96)$ \\
\hline $\begin{array}{l}\text { Cinsiyet } \\
\text { Kadın } \\
\text { Erkek }\end{array}$ & $\begin{array}{l}70(55.1) \\
97(53.6)\end{array}$ & $\begin{array}{l}57(44.9) \\
84(46.4)\end{array}$ & $\begin{array}{c}127 \\
181 \\
(0.791)\end{array}$ \\
\hline Sigara içme öyküsü & $14(37.8)$ & $23(62.2)$ & $37(0.037)$ \\
\hline Obezite & $24(14.4)$ & $42(29.8)$ & $66(0.001)$ \\
\hline $\begin{array}{l}\text { Komorbid hastalıklar } \\
\text { HT } \\
\text { DM } \\
\text { KKY } \\
\text { KBY } \\
\text { KAH } \\
\text { KOAH } \\
\text { Operasyon öyküsü } \\
\text { Malignite varlığı } \\
\quad \text { Hematolojik/solid } \\
\text { KT öyküsü } \\
\text { Diğer komorbid hastalıklar }\end{array}$ & $\begin{array}{c}68(48.2) \\
43(44.8) \\
9(30) \\
10(31.3) \\
19(35.8) \\
29(58) \\
7(53.8) \\
20(47.6) \\
5(41.7) / 15(50) \\
9(36) \\
46(50.5)\end{array}$ & $\begin{array}{c}73(51.8) \\
53(55.2) \\
21(70) \\
22(68.7) \\
34(64.2) \\
21(42) \\
6(46.2) \\
22(52.4) \\
7(58.3) / 15(50) \\
16(64) \\
45(49.6)\end{array}$ & $\begin{array}{c}141(0.052)^{\star *} \\
96(0.025) \\
30(0.004) \\
32(0.006) \\
53(0.003) \\
50(0.558) \\
13(0.997) \\
42(0.355) \\
12 / 30(0.826) \\
25(0.056)^{\star *} \\
91(0.402) \\
\end{array}$ \\
\hline
\end{tabular}

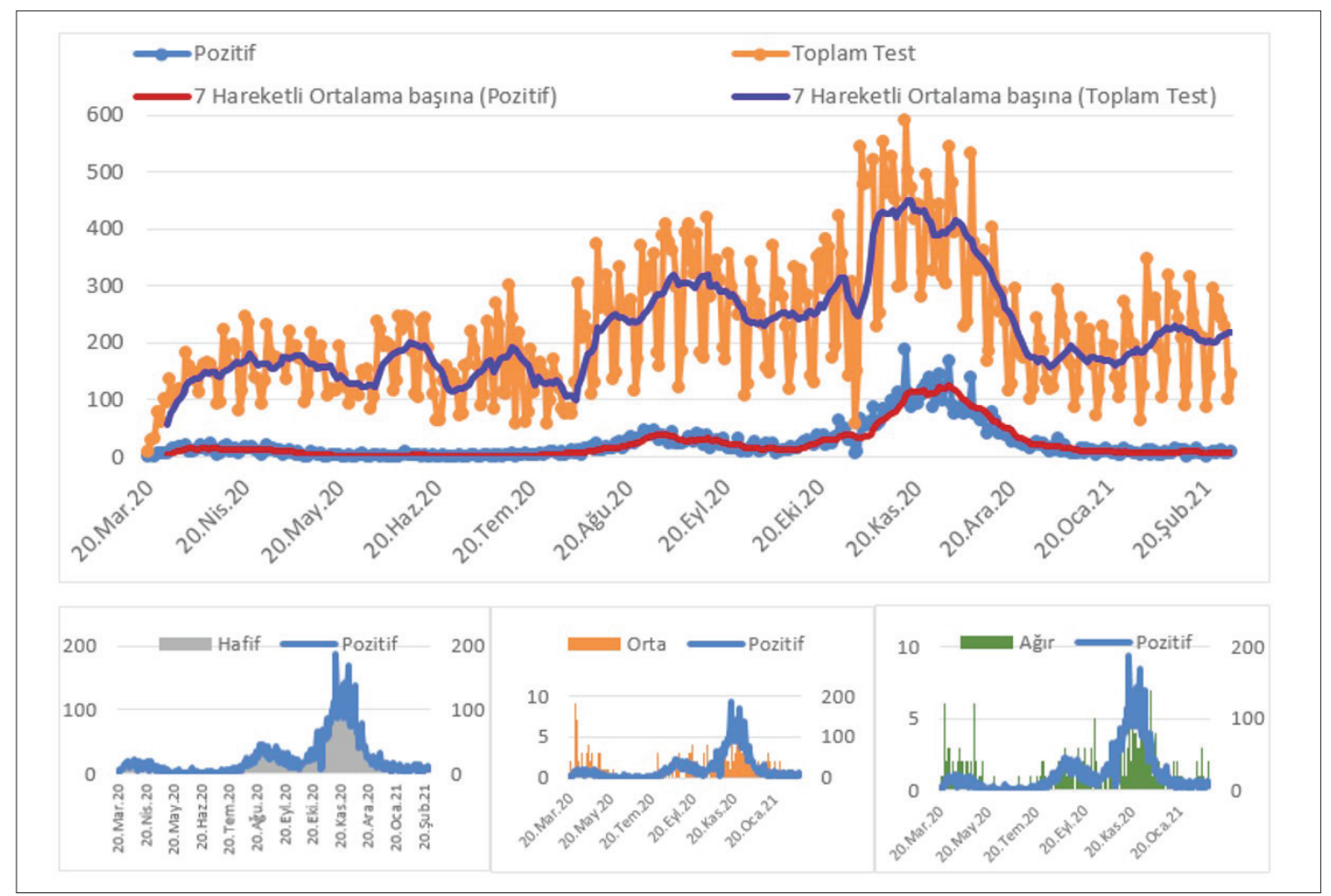

Şekil 4. Toplam test sayısı, pozitif olgular ve klinik düzeylerin aylara göre dağılımları (7 hareketli ortalama başına toplam test ve pozitif olgu). 


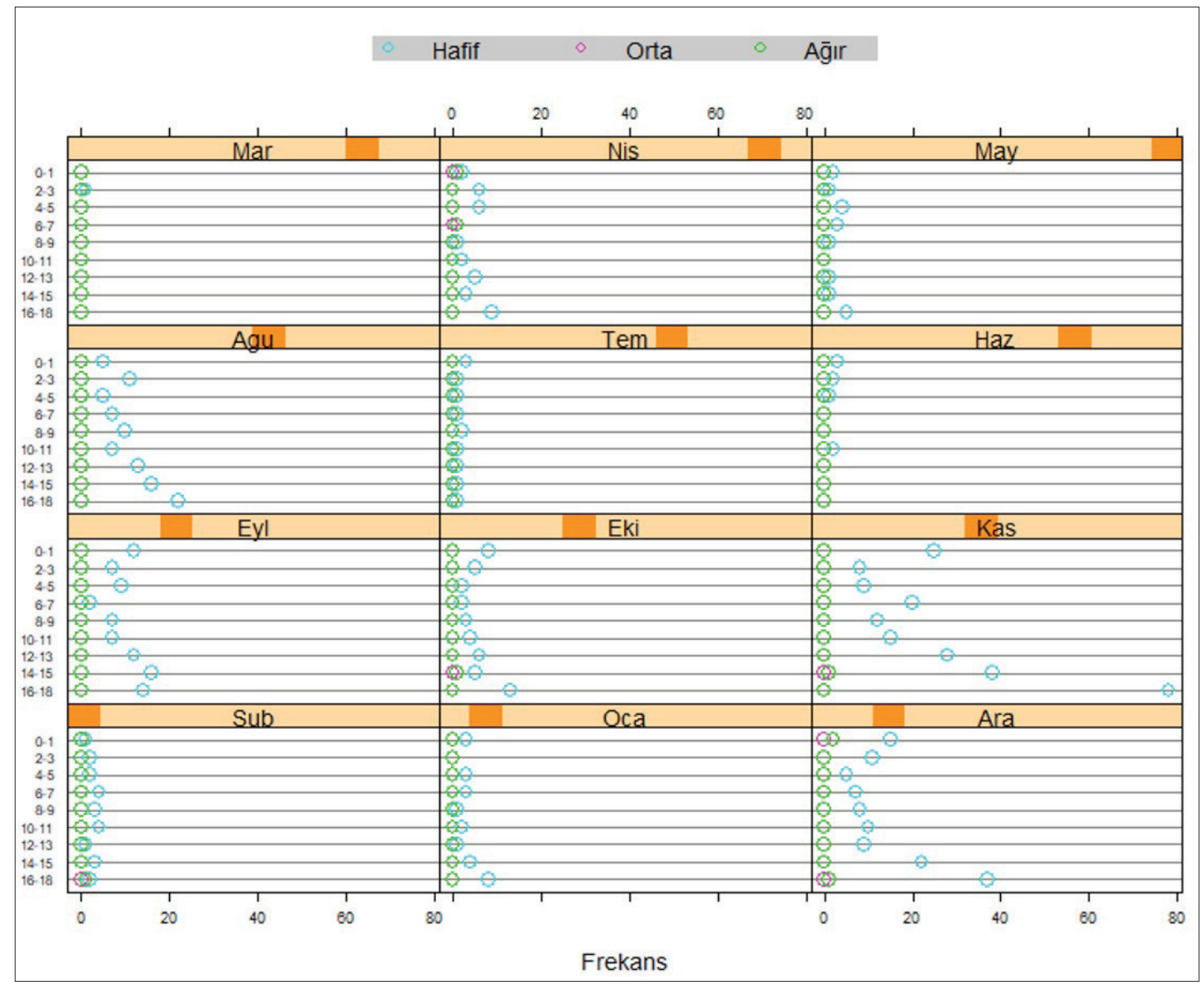

Şekil 5. COVID-19 pozitif olguların aylara göre dağııımı (Pediatrik hastalar).

durumları ile değișkenlik gösterebilir.

Bir yll boyunca SARS-CoV-2 ile infekte olan hastalar, infeksiyonu geçirme ağıllkklarına göre üc grupta sınıflandırılmıștır. Toplamda izlem süresinde hastaların istatistiksel olarak anlamlı bir coğunluğu (\%92.7) infeksiyonu hafif kategori olarak tanımlanan, hastaneye yatıs gerektirmeden gecirmiștir. Eriskin grupta kendi içinde hafif infeksiyon geçiren kișiler ağırlıkta olmasına karșın, pediatrik yaș grubunda istatistiksel olarak anlamlı derecede COVID-19 kliniği daha hafif seyretmiștir. Hafif, orta, ağır olguların salgın bașladığından beri aylara göre seyrine bakıldığında; ilk dört ayda orta ve ağır olarak sınıflanan olguların, tüm olguların \%25-50'sini olusturduğu, daha sonraki aylarda ise $\% 10$ ve altına indiği görülmektedir. Pandeminin ilk aylarında hem ülke hem de hastane olarak bir karısıklık yașandığı, daha sonra tanı ve tedavi hizmetlerinin daha standart olması, proaktif davranılması, tüm laboratuvar ve klinik bölümlerin deneyim kazanılmasıyla hasta yönetiminin iyilesmesine neden olarak hastaların ağır kategorisine geçmesini engellemiş olabilir.

Pediatrik hastaların değerlendirildiği bir sistematik derlemede, olgularm \%96.5'i hafif (\%14.2'si asemptomatik, \%82.3'ü hafif), \%3.3'ü ağır klinik grubunda sınıflandırılmıștır. Tüm calıșmalarda sadece bir ölüm bildirilmiștir ${ }^{[15]}$. Bu calısmada da benzer olarak pediatrik grubun \%98.9'u COVID-19 infeksiyonunu hafif geçirmiștir. Sekiz olgu ağır kategorisinde yoğun bakımda izlenmiștir. Sekiz olgunun beșinde komorbidite bulunmaktadır. Ağır pediatrik olguların $0-1$ yas grubunda bulunan, sağ kalp yetmezliği ve primer immün yetmezlik komorbiditileri olan iki hasta kaybedilmiștir.

COVID-19'un erișkinlerdeki klinik özelliklerini sistematik olarak derleyen bir makalede, 3062 


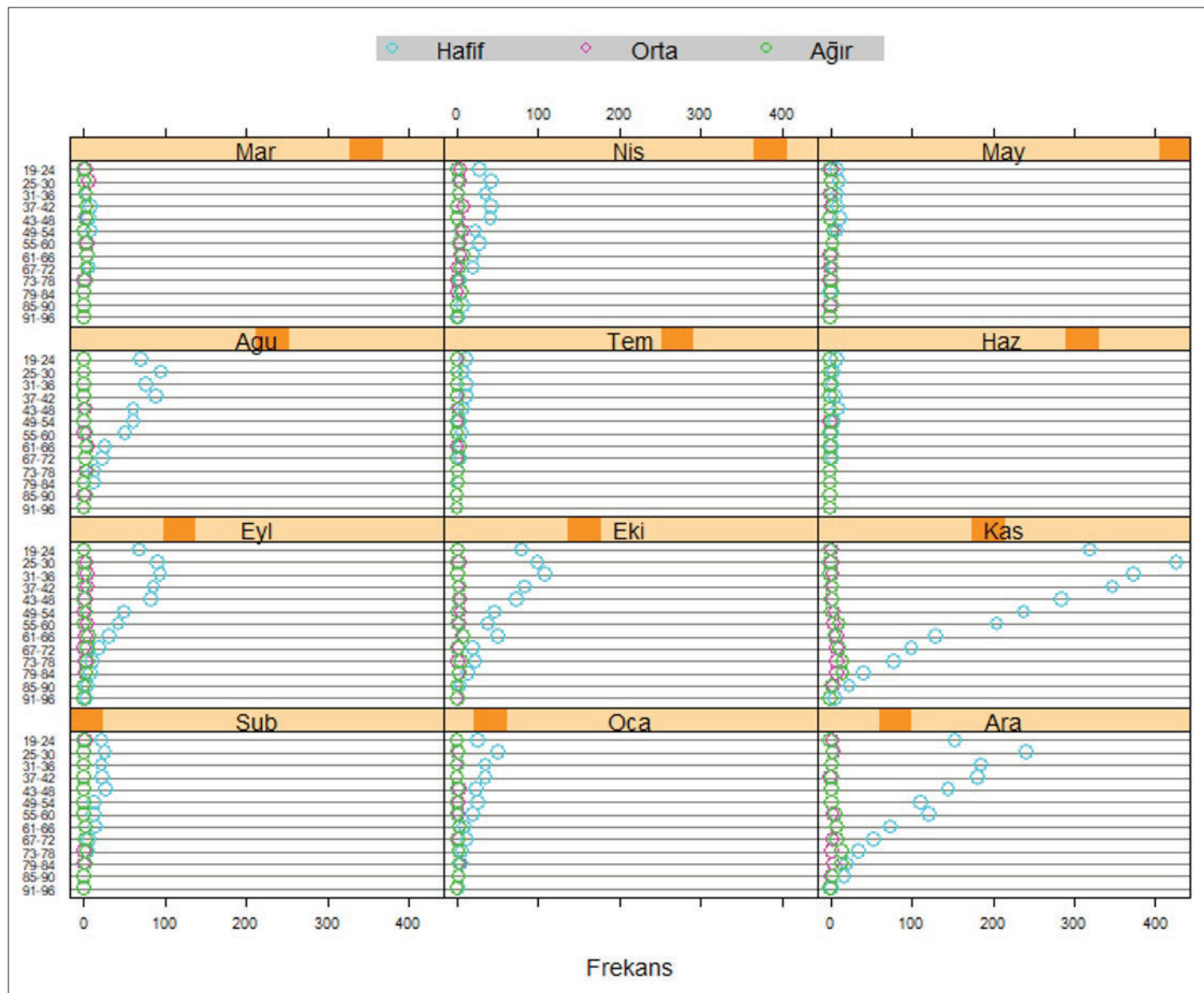

Şekil 6. COVID-19 pozitif olguların aylara göre dağııımı (Erişkin hastalar).

hastayı içeren toplam 38 çalıșma sonuçları analiz edilmiștir. İnfekte hastaların yüksek oranda erkek olduğu (\%56.9), solunum yetmezliği veya akut solunum sıkıntısının \%19.5 ve ölüm oranının \%5.5 olduğu bildirilmiștir ${ }^{[18]}$. Çin'de genis hasta grubu ile yapılan diğer bir çalıșmada, olguların \%87'sinin 30 ila 79 yassları arasında olduğu, infeksiyonu \%81'inin hafif (pnömoni olmayan veya hafif pnömoni), \%14'ünün ciddi ve \%5'inin kritik düzeyde (solunum yetmezliği, septik sok ve/veya coklu organ disfonksiyonu veya yetmezliği) olduğu saptanmıstır ${ }^{[19]}$. Bu seride, erișkin hastaların yaklașı \%8'i COVID-19'u orta ve ağır düzeyde geçirmiștir ve erkek hastaların oranı kadın hastalara göre istatistiksel olarak anlamlı derece yüksektir. Ağır geçiren hastaların yas medyanı 66,5 bulunmuștur. Ağır kategorisinde de bulunan 300 erișkin hastanın \%47'si kaybedilmiștir. Ölüm oranları diğer pozitif bulunan hastalarla karșılaștrıldığında, toplam pozitif olan hastaların $\% 1.8$ 'i, ağır kategorisinde bulunan hastaların $\% 45.8$ 'i ve yoğun bakımda tedavi gören hastaların \%57.3'ü ex olmuștur. Ölen hastaların kadın-erkek cinsiyeti açısından bir fark bulunamamıștır. Yoğun bakımda tedavi gören hastalarda, diğer hastalara göre istatistiksel olarak önemli derecede daha fazla ölüm görülmüstür. Daha önce bildirilen oranlara göre bu hasta serisinde de orta ve ağır hasta gruplarının yüzde oranları daha azdır. Genel ölüm oranları Türkiye (\%2.6) ve dünya (\%2.1) verilerine göre daha düșüktürr ${ }^{[2,8,14]}$.

COVID-19 infeksiyonunda hastanın yașı, hastalık siddeti ve mortalite için risk faktörlerinden biridir. Bildirilen olgularda, 60 yașından büyük COVID-19 hastalarında daha yüksek oranlarda solunum yetmezliği geliștiği ve daha uzun süreli tedaviye ihtiyac duydukları gösterilmiștir. COVID-19'un klinik bulgularının yas, cinsiyet, DM, $\mathrm{HT}$, KAH, KOAH ve kanser gibi altta yatan 
komorbiditelere bağlı olarak farklı seyredebildiği ve prognozun olumsuz yönde etkilenebileceği bildirilmiștir $^{[20]}$. Bu çalıșmada, infeksiyonu ağır geçiren grupta sağ kalanların yaș medyanı 61, ölen hastaların yas medyanı ise 73 bulunmuștur. Ölen hastaların istatistiksel olarak önemli oranda 60 yas ve üzeri (\%85) hastalar olduğu görülmüștür. Ağır kategorisindeki hastaların komorbidite oranları araștırılmıștır. Sigara içme öyküsü, obezite, $\mathrm{DM}, \mathrm{KKY}, \mathrm{KBY}, \mathrm{KAH}$ komorbiditileri istatistiksel olarak anlamlı derecede kötü prognoz ve ölüm ile ilișkili bulunmuștur. Kemoterapi öyküsünün olması ve HT komorbiditelerinin, analizde $\mathrm{p}$ değeri 0,1 'e yükseltildiğinde ölüm riski ile sınırda anlamlılık düzeyinde ilișkili olduğu görülmüștür. Bașta $\mathrm{KOAH}$ olmak üzere, malignite ve operasyon geçirme öyküsü gibi diğer komorbiditelerin ölüm üzerine etkisi bulunmamıstır. Guan WJ ve ark. ağır klinikle seyir gösteren COVID-19'li olgularda; HT (\%32.7), KAH (\%33.9), serebrovasküler hastalıklar (\%50.0), DM (\%34.6), KOAH (\%62.5), KBY $(\% 38.1)$ ve malignite $(\% 50,0)$ gibi komorbid hastalıklarının bulunduğu sonucuna varmıș$\operatorname{lardir}^{[21]}$. Ayrıca DM hastalarında hiperglisemik durum inflamatuar sitokinler üzerinde artıșa sebep olması; ağır COVID-19 kliniğindeki hiperinflamatuar durumu daha da arttırarak hastalığın daha ciddi klinik seyir göstermesine ve mortalitenin yükselmesine sebebiyet verebilmektedir ${ }^{[22]}$. Obez hastalarda COVID-19 kliniğinin daha ağır seyrettiği bildirilmekle birlikte ${ }^{[23]}$, mevcut $\mathrm{KAH}$ veya KKY'si bulunan olgularda COVID-19'un yarattığ1 hipoksik durumun bahsi geçen kronik kalp hastalığı bulunan bireylerde mortalite oranlarının yükselmesine sebep olduğu bildirilmiștir ${ }^{[24]}$. Sipahi ve arkadașları COVID-19 infeksiyonu geçiren 23 hemodiyaliz hastası KBY'li olgu üzerinde yapmıs oldukları calıșmada da KBY'li hastalarda COVID-19'un mortalitesinin \%13 (23 hasta/3 ölüm) seviyesinde seyrettiği saptanmıștır, 23 hastalık grubun tamaminda (\%100) hipertansiyon ve \%52'sinin koroner arter hastalığı gibi komorbit hastalıkların bulunması dikkat çekicidir [25]

$\mathrm{Bu}$ çalıșmada salgının bir yıllık aylara göre seyri izlendiğinde, pozitif olgu sayıların 2020 Kasım ayında en yüksek duizeye çıtığı görülmüștür. Kasım ayına ait pozitif olgular, bir yıllık pozitif olguların \%36.8'ini içermektedir. Ege Üniversitesi Tıp Fakültesi Hastanesi'nde en yüksek pozitif olgu sayısı 16 Kasım 2020 tarihinde gözlenmiștir. Güncel olarak ülkemizde vaka sayılarının en yüksek olduğu zaman ise Nisan 2021 tarihindedir $^{[8]}$. İzmir'de 30 Ekim 2020 tarihinde 6,9 siddetinde deprem olmus ve özellikle hastanenin bulunduğu Bornova semtinde bazı apartmanlar yıkılmıs, cok sayıda kiși yaralanmıș ve ölmüștür. Evsiz kalan kișiler çadır ortamlarında yașamlarını sürdürmüs ve COVID-19'a kontrolsüz olarak maruz kalmıșlardır. Bölgemizde Kasım ortasında COVID-19'un pik yapmasının nedeni buiyük olasılıkla İzmir depremine bağlıdır. Yine deprem ile bağlantılı olarak, bu seride "ağı" olgular 9-14 Aralık 2020 tarihleri arasında en yüksek değere ulașmiștır.

Sonuç olarak; bölgemizde pandemi bașlang1cindan itibaren bir ylllk sürede COVID-19 hem pediatrik hem de erișkin grupta büyük oranda hastaneye yatıs gerekmeksizin, hafif hastalık tablosu ile gecirilmiștir. COVID-19 infeksiyonu sıklığı bir yıllık süre içinde toplam hasta sayısı üzerinden \%10.5 oranında pozitif bulunmuștur. Toplumda kadın ve erkek eșit oranlarda COVID-19 ile infekte olmus, ancak ağır klinik düzey hastalık tablosu erkeklerde ve 60 yas üzerinde daha sık görülmüștür. Pandemi bașlangıcında orta ve ağır olgular tüm hastaların yarısını oluștururken, ilk dört aydan sonra bu oran azalmıș ve yıllık sürec tamamlanırken ağır hastalık tabloları görülme oranı \%4-5 seviyesine inmiștir. Toplamda COVID-19 olan hastaların \%1.8'i kaybedilmiștir. Ölüm oranları özellikle yoğun bakımda tedavi gören hastalarda oldukça yüksek oranlarda (\%57.3) bulunmuștur. Sigara içme öyküsü, obezite, DM, $\mathrm{KKY}, \mathrm{KBY}, \mathrm{KAH}$ komorbiditeleri ile $\geq 60$ yas; kötü prognoz ve ölüm ile ilișkili bulunmuștur. Kemoterapi öyküsünün olması ve HT komorbiditeleri ölüm riski ile sınırda anlamlılık düzeyinde ilișkili olduğu görülmüștür. Bașta KOAH olmak üzere, malignite ve operasyon gecirme öyküsü gibi diğer komorbiditelerin ölüm üzerine etkisi bulunmamıștır. Bölgemizde, en fazla olgu sayısı 2020 yılı Kasım-Aralık aylarında kaydedilmiș ve 16 Kasım 2020 tarihinde COVID-19 infeksiyonu pik yapmıștır.

\section{ETIK KURUL ONAYI}

Çalıșma için, Sağlık Bakanlığı resmi izni ve Ege Üniversitesi Tıbbi Araștırmalar Etik Kurulu'n- 
dan izin alınd (Tarih: 27.05.2021, Karar No: 21-5.1T/54)

\section{ÇIKAR ÇATIŞMASI}

Yazarlar bu makale ile ilgili herhangi bir çkar çatıșması bildirmemiștir.

\section{YAZAR KATKISI}

Anafikir/Planlama: CC, MBB, MS, AZ, MAÖ, ME

Analiz/Yorum: MBB, IE, ME

Veri sağlama: HP, MT, ST, EUS, FKA

Yazım: CC, MS, MAÖ, ME

Gözden Geçirme ve Düzeltme: IE, İC, FKA, SY, HP, MT

Onaylama: CC, MS, HP, MT, RS, MAÖ, FLA, MBB, RS, AZ, IE, IC

\section{KAYNAKLAR}

1. Yin $Y$, Wunderink RG. MERS, SARS and other coronaviruses as causes of pneumonia. Respirology 2018;23(2):130-7.

2. WHO Coronavirus disease (COVID-2019) situation reports. https://www.who.int/emergencies/diseases/novel-coronavirus-2019/situation-reports. (Erişim tarihi: 30 Nisan 2021).

3. Sami $R$, Soltaninejad $F$, Amra B, Naderi $Z$, Javanmard $S H$, Iraj $B$, et al. A one-year hospital-based prospective $\mathrm{CO}$ VID-19 open-cohort in the Eastern Mediterranean region: The Khorshid COVID Cohort (KCC) study. PLoS One 2020;15(11):e0241537.

4. Wang D, Hu B, Hu C, Zhu F, Liu X, Zhang J, et al. Clinical Characteristics of 138 Hospitalized Patients With 2019 Novel Coronavirus-Infected Pneumonia in Wuhan, China. JAMA 2020;323(11):1061-9.

5. Zhou $F, Y u T, D u R$, et al. Clinical course and risk factors for mortality of adult inpatients with COVID-19 in Wuhan, China: a retrospective cohort study. Lancet 2020;395(10229):1054-62.

6. Ciceri F, Castagna A, Rovere-Querini P, De Cobelli F, Ruggeri A, Galli $L$, et al. Early predictors of clinical outcomes of COVID-19 outbreak in Milan, Italy. Clin Immunol 2020;217:108509.

7. Bertsimas $D$, Lukin $G$, Mingardi L, Nohadani O, Orfanoudaki $A$, Stellato $B$, et al. COVID-19 mortality risk assessment: An international multi-center study. PLoS One 2020;15(12):e0243262.

8. T.C. Sağıı Bakanlığı, Yeni koronavirüs Hastalığı (COViD-19), Available from: https://covid1 9bilgi.saglik.gov.tr/ tr/. (Erişim tarihi: 30 Nisan 2021).

9. Fang F, Chen $Y$, Zhao D, Liu T, Huang Y, Qui L, et al. Recommendations for the Diagnosis, Prevention, and Control of Coronavirus Disease-19 in Children-The Chinese Perspectives. Front Pediatr 2020;8:553394.
10. T.C. Sağlık Bakanlığı, COVID-19 (SARS-CoV-2 Enfeksiyonu) Erişkin Hasta Tedavisi, 7 Mayıs 2021. Available from: https://covid19.saglik.gov.tr/Eklenti/40719/0/covid-19rehberieriskinhastayonetimivetedavipdf.pdf. (Erişim tarihi: 17 Mayıs 2021).

11. Bioeksen, Bio-speedy ${ }^{\circledR}$ SARS CoV-2 Triple Gene RT-qPCR. Available from: https://www.bioeksen.com.tr/sars-cov2triple-gene-rtqpcr-kit. (Erişim tarihi: 16 Mayıs 2021).

12. Life Sciences. RTA Laboratories. Diagnovital SARS-CoV-2 Multiplex. Diagnovital SARS-CoV-2 Real time PCR kit. Available from: http://www.a1 lifesciences.com.tr/productdetail/sars-cov-2-real-time-pcr-kits-85. (Erişim tarihi: 16 Mayıs 2021).

13. Gensutek, DS Nano and Biotechnology Product Tracing and Tracking Co. DS CORONEX COVID-19 Multiplex Real Time-qPCR Test Kit. Available from: http://coronexkit.com. (Erişim tarihi: 16 Mayıs 2021).

14. Johns Hopkins University CSSE. COVID-19: Daily dashboard. Available from: https://dgalerts.docguide.com/ covid-19-daily-dashboard292?overlay $=2 \& n l \_r e f=n e w s-$ letter\&pk_campaign=newsletter\&nl_eventid=87462\&nl_ campaignid $=3641 \& p w \_s i t e l D=25 \& n c o v \_s i t e=c o v i d-19 \&-$ MemberID=302808100 (Erişim tarihi: 19 Mayıs 2021).

15. de Souza TH, Nadal JA, Nogueira RJN, Pereira RM, Brandão MB. Clinical manifestations of children with COVID-19: A systematic review. Pediatr Pulmonol. 2020;55(8):1892-9.

16. Guan WJ, Ni ZY, Hu Y. Clinical Characteristics of Coronavirus Disease 2019 in China. N Engl J Med 2020;382(18):170820.

17. Korkmaz MF, Türe E, Dorum BA, Kılıç ZB. The Epidemiological and Clinical Characteristics of 81 Children with COVID-19 in a Pandemic Hospital in Turkey: an Observational Cohort Study. J Korean Med Sci 2020;35(25):e236.

18. Zhu J, Ji P, Pang J. Clinical characteristics of 3062 COVID-19 patients: A meta-analysis. J Med Virol 2020;92(10):190214

19. Wu Z, McGoogan JM. Characteristics of and Important Lessons From the Coronavirus Disease 2019 (COVID-19) Outbreak in China: Summary of a Report of 72314 Cases From the Chinese Center for Disease Control and Prevention. JAMA 2020;323(13):1239-42.

20. Liu Y, Mao B, Liang S. Association between age and clinical characteristics and outcomes of COVID-19. Eur Respir I 2020;55(5):2001112.

21. Guan WJ, Liang WH, Zhao Y. Comorbidity and its impact on 1590 patients with COVID-19 in China: a nationwide analysis. Eur Respir J 2020;55(5):2000547.

22. Michalakis K, Ilias I. COVID-19 and hyperglycemia/diabetes. World J Diabetes 2021;12(5):642-50.

23. Curtin KM, Pawloski LR, Mitchell P, Dunbar J. COVID-19 and Morbid Obesity: Associations and Consequences for Policy and Practice. World Med Health Policy 2020;9:10.1002/ wmh3.361. 
24. Tomasoni D, Italia L, Adamo M. COVID-19 and heart failure: from infection to inflammation and angiotensin II stimulation. Searching for evidence from a new disease. Eur J Heart Fail 2020;22(6):957-66.

25. Sipahi S, Dheir H, Toçoğlu A. Characteristics and mortality determinants of COVID-19 patients undergoing hemodialysis. Turk J Med Sci 2021;51(2):421-7.

\section{Yazıșma Adresi/Address for Correspondence}

Dr. Mehmet SOYLU

Ege Üniversitesi Tıp Fakültesi Hastanesi, Tibbi Mikrobiyoloji Anabilim Dalı, İzmir-Türkiye

E-posta: mehmet.soylu@ege.edu.tr 